\title{
GAAP/Tax Differences In Accounting For Nonqualified Employee Stock Options: The Gathering Storm
}

\author{
Raymond Placid, Florida Gulf Coast University \\ Joseph C. Rue, Florida Gulf Coast University \\ Ara G. Volkan, Florida Gulf Coast University
}

\begin{abstract}
The escalating size of compensation packages to senior managers and investor disillusionment resulted in the issuance of FAS 123(R). Under the current rules, the grant date fair value of employee stock options (ESO) are expensed over the vesting period. The two primary methods used to value ESO are the Black-Scholes closed form equation and the lattice model. Several studies suggested an alternative Simple model for valuing ESO that marks the option expense to market in succeeding financial statement dates and allows for the staggered exercise dates of option holders. This approach is easy to understand, would have a low cost of implementation, and offers a superior estimate of the true cash flow effects and economic injury associated with the opportunity cost to shareholders of ESO exercise. Moreover, the Simple model would head off another threat to the legitimacy of the FASB that is unfolding in the U.S. Congress as Senator Carl Levin holds hearings on ESO in the Senate Permanent Subcommittee on Investigations to decide what to do about the multi-billion dollar gap between what companies report to stockholders as ESO expense and what they deduct on their tax returns. In addition, this gap results in highly controversial rules of accounting and reporting for the favorable impact of the deductions in the financial statements.
\end{abstract}

\section{INTRODUCTION}

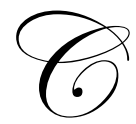

oming on the heels of the scandals involving the backdating of the grant date of employee stock options (ESO), Senator Carl Levin (D-Michigan) is holding hearings on the wide gap between what companies expense for ESO in their financial statements under FAS 123(R) and what they actually deduct on their tax returns when the ESO are exercised (Levin, 2007). According to the research conducted by the Committee staff, the tax deductions are running at ten to twelve times the expenses reported to the stockholders. The purpose of the hearings is to bring clarity to ESO accounting and reporting by ensuring that what companies report as ESO expense to their stockholders match the economic injury they are allowed to deduct under the tax rules. One proposal is to require uniform accounting and reporting rules for both tax and financial accounting for ESO.

The Committee staff research further shows that, in 2004, 3,200 companies produced an aggregate tax deduction that was $\$ 43$ billion more than what ESO expense would have been under FAS 123(R). Moreover, just 250 companies produced 82 percent of the gap. In addition, the book-tax gap was 30 percent of the entire book-tax difference reported in 2004.

Typically, the deferred tax assets recorded when the ESO expenses are accrued cannot counterbalance the tax refund received when the ESO are exercised, resulting in a credit deficiency in the journal entry. FAS 123(R) requires that the deficiency be credited to contributed capital and a financing cash inflow be reported in the cash flow statement for the reduction in taxes in excess of deferred tax assets. This highly controversial approach is consistent if one subscribes to the view that issuing ESO and its tax advantages are primarily a part of the capital raising process. Thus, the excess refunds cannot result in reductions in tax expense and cannot be part of the operating cash flows. 
The alternative view holds that ESO are equivalent to salary expenses. Company boards grant ESO to compensate executives and the cash flow to the firm when stocks are issued is a peripheral consideration at best. Indeed, recent research results show that firms increased the use of restricted stock and decreased the use of ESOs in compensation packages after FAS 123(R) was issued, but the total cost of compensation stayed the same (Carter, Lynch, and Tuna, 2007).

\section{PURPOSE}

The purpose of this paper is to offer an alternative model of ESO valuation which more readily captures the wealth effects on shareholder value. Since valuing and expensing options have been accepted by stakeholders, it is time to take the final step of starting to continuously fair value options until they are exercised and capture the true cost of these transactions in company financial statements. Delaying this final step in the evolution of ESO accounting may provide an opportunity for politicians to dominate the FASB through the SEC, using the gap between the reported expenses and the tax deductions taken as an excuse.

\section{BACKGROUND}

The history of whether or not firms should recognize the expense associated with issuing ESO, and the valuation method used to determine the expense, is extensive (Frederickson, Hodge, and Pratt, 2006). In 1972, the Accounting Principles Board issued Opinion No. 25, which tied the valuation of the ESO to its intrinsic value on the initial grant date. If the exercise price of the option was greater than or equal to the current market price of the firm's stock (at or out of the money), the firm was not required to recognize any expense (APB, 1972).

Between 1978 and 1993, the Financial Accounting Standards Board (FASB) acknowledged that the value, or price, of an option is comprised of the intrinsic value and the time value and issued several documents arguing for a change in emphasis in the valuation of ESO (FASB, 1978, 1985, 1986, and 1993; FASC-AAA, 1994). In 1995, the FASB issued FAS 123 which encouraged, but did not mandate, that firms recognize the expense associated with the issuance of ESO using a fair valuation method.

Rising levels of CEO compensation and investor unrest led to increasing calls for the immediate expense recognition for ESO in corporate financial statements (Apostolou and Crumbley, 2001 and 2005; Bartow and Mohanram, 2004; Botosan and Plumlee, 2001; Delves, 2002; Doyle, 1997; Mellman and Lillien, 1996; Moyer and Weihrich, 2000). While the FASB continued to issue documents concerning ESO (FASB, 2002a and 2002b), opposition from firms fearful of negative impacts on their financial position resulted in a stand-off lasting a decade.

In December 2004 the FASB issued Standard No. 123 (R) that required all publicly held firms to recognize compensation costs related to share-based transactions in their financial statements and brings global harmony to accounting for ESO (IASB, 2002 and 2004) by the end of 2005. Originally, FASB favored the use of a lattice model exclusively for option valuation, but backed off due to significant opposition from various stakeholders (FASB, 2004) and indicated a preference for a closed form equation model or a lattice model approach as appropriate for valuing ESO.

While publicly held firms must expense the grant date fair value of the ESO over the vesting period, nonpublicly held firms may elect to measure the ESO at intrinsic value at the grant date and then re-measure the intrinsic value at each financial statement date until the ESO are exercised. This approach creates contributed capital amounts that cumulate, with changes in the cumulative amounts recorded as expense at each measurement date. Thus, decreases in stock prices will result in negative expenses (credits). Under this approach of continuous fair valuation of ESO, deferred tax assets will be equal to the tax impact of the deduction allowed under the tax code.

\section{ALTERNATIVE OPTION VALUATION MODELS}

From a financial investment perspective, the true economic cost to a firm of utilizing ESO as a method of compensation is the opportunity cost associated with the difference between the exercise price of the option and the market price of the stock upon exercise. This intrinsic value represents foregone capital that could have been raised 
by the firm if the stock had been issued directly at current market prices. Therefore, the choice of which option valuation model should be used to recognize the ESO expense should be driven by the determination of which model most accurately reflects, in Senator Levin's words, this economic injury or loss of shareholder wealth (Aboody, Barth, and Kasznik, April 2004; Balsam, 1994; Baviera and Walther, 2004; Best, Rue, and Volkan, 2002; Briloff, 2003; Dechow and Sloan, 1996; Deshmukh, Howe, and Luft, 2004; Dyson, 2004; Hill and Stevens, 1997; Hull and White, 2004; Jordan, Vann, and Clark, 2005; Lobo and Rue, 2000; Pacter, 2004; Perspectives, 1994; Rue, Volkan, Best, and Lobo, 2003; Siegel, 2006; Tucker and Shimko, 1995; Wallace, 1984).

Since 1995, many firms have voluntarily acknowledged the effects of ESO on financial results through footnote disclosures, using the Black-Scholes (BS) or Black-Scholes-Merton (BSM, for stocks that pay dividends) model for option valuation (Aboody, Barth, and Kasznik, May, 2004; Beams, Amoruso, and Richardson, 2005; Robinson and Burton, 2004). The BS model is a closed form equation that, when supplied with several estimated variables, computes a fair option value that includes both intrinsic and time value (Black and Scholes, 1973). Eaton and Prucyk (2005) provide an illustration of the BSM option valuation method using Excel spreadsheet software.

However, a number of issues and complex assumptions make the BS model a poor choice for option valuation to reflect the ESO expense recognition (FASC-AAA, 2004 and 2005; Hemmer, Matsunaga, and Shevlin, 1994; Kirschenheiter, Mathur, and Thomas, 2004; Moehrle and Reynolds-Moehrle, 2004; O'Shaughnessy and Rashty, 2007). First, the model was originally developed to value exchange-traded options that have limited lives. The typical ESO has a longer life (five to ten years) that often begins when a required vesting period ends. Exchange traded options also have a liquid secondary market that facilitates low cost transactions, resulting in regular price discovery. In contrast, the ESO are not transferable. In addition, BS was developed to value a European option that cannot be exercised until maturity. Once the vesting period is complete, the ESO can be exercised at the discretion of the employee, in effect an American option. Finally, a key input in the BS model is volatility. Most volatility estimates are derived from historical returns, leaving no opportunity for the incorporation of changing market conditions and the resulting effects on shareholder wealth.

A lattice model based on a series of discrete future price paths is an alternative option valuation method. The simplest lattice is a binomial model that assumes the current stock price can diverge one of two possible paths in the coming period. There is some sentiment that a lattice valuation model is superior to the BS model for the ESO expense recognition. Barenbaum, Schubert, and O'Rourke (2004) highlight two advantages of a lattice model, including an ability to incorporate varying exercise patterns on the part of option holders and the flexibility to capture changes in the volatility of the underlying stock's rate of return. The authors note that the possibility of early exercise reduces the total option value at the grant date (reducing the time value of the option price), and thus the overall impact on reported earnings is less when the ESO are valued using a lattice model. Baril, Betancourt, and Briggs (2005) and Folami, Arora, and Alli (2006) provide an illustration of ESO valuation using a lattice model program in Excel spreadsheet software.

A third alternative, which is not allowed for use in FAS 123(R) except for non-publicly held companies, is the continuous revaluation of ESO using intrinsic values at successive financial reporting dates. Prior research illustrates how the use of different valuation models and assumptions result in option values which may be dramatically different. In addition, they argue that these models do not capture the true cost to shareholders of issuing the ESO and that the ESO should be revalued at each reporting date until they are exercised, reflecting a dynamic expense rather than a one-time, static valuation. Because the timing of the exercise is dynamic, and lies with the option holder, a good valuation method should allow for extending the expense period from the vesting date to the actual exercise date (Finch, Rue, and Volkan, 2007; Rue, Volkan, Best, and Lobo, 2003; Best, Rue, and Volkan, 2002).

\section{SENATOR LEVIN AND THE ESO GAAP/TAX DIFFERENCES: THE GATHERING STORM}

FAS 123 considered ESO to be essentially compensation in nature. Under FAS 123, any exercise date reduction in taxes payable that was in excess of the deferred tax assets accumulated when the original fair value of the ESO was expensed would be treated as a reduction in tax expense and be reported as an operating cash flow. 
Using the dubious argument that ESO are essentially capital raising transactions, FAS 123(R) altered the rules and required that the excess be credited to contributed capital and shown as a financing cash flow.

\section{Tax Law Considerations}

Section 83 of the Internal Revenue Code (IRC), first enacted in 1969, is the key statute for the taxation of non-qualified ESO. Under section 83, if the option has a readily ascertainable value on the grant date, then the employer takes a deduction for that value. Otherwise, the employer is allowed to deduct the intrinsic value of the option on the date of exercise. The employee reports the same amount as taxable income. While a 1993 law capped the executive compensation deduction the firms can take at $\$ 1$ million, nonqualified stock options were exempt from this cap.

The option fair value is readily ascertainable if all of the following conditions exist:

1. The option is freely transferable by the recipient;

2. The option is immediately exercisable by the recipient;

3. The option is not subject to any condition that has a significant impact on its fair value; and,

4. The fair market value of the option privilege is readily ascertainable.

An option privilege is the opportunity to benefit during the option's exercise period from any increase in the value of the property or financial instrument subject to the option, without risking any capital. Therefore, the fair value of the option is not merely the difference between the option's exercise price and the value of the underlying item subject to option, but also includes the value of the option privilege for the remainder of the exercise period. To satisfy requirement number four above, the value of the entire option privilege must be readily measurable. Thus, it is necessary to consider: (i) whether the value of underlying item subject to option can be ascertained; (ii) the probability of any such ascertainable value increasing or decreasing; and (iii) the length of the period during which such option can be exercised.

While it is clear that conditions three and four in the above list can be met, conditions one and two make it impossible for companies to take a tax deduction for ESO at the grant date. Under financial accounting rules, condition number four provides the only method for computing ESO fair values and their subsequent amortization over the vesting period under FAS 123(R). The other conditions do not have counterparts in financial accounting and reporting. Thus, timing differences between ESO expenses and ESO tax deductions will arise even when only in the money ESO are considered. Those ESO that are out of money and are allowed to lapse create further complications under the current rules and are beyond the scope of this paper.

\section{The Statement Of Senator Carl Levin}

According to the Congressional record, Senator Carl Levin and his research staff introduced testimony that show the wide gap between the financial accounting for ESO expenses and the tax deduction taken by companies under section 83. The Committee staff asked the IRS to perform analyses of the new M-3 Schedule which is filed by companies to identify the sources of their book-tax differences. The staff also asked nine companies to prepare a schedule comparing the ESO expenses that they would have reported had they used FAS 123(R) rules to the tax deductions they took in 2004.

The entire book-tax difference reported on Schedule M-3 for 2004 was $\$ 143$ billion, thirty percent of which, or $\$ 43$ billion, was due to ESO. Of the approximately 3200 corporations reporting this book-tax difference, 250 companies accounted for the eighty-two percent of the $\$ 43$ billion, or $\$ 35$ billion, indicating an average differential of $\$ 140$ million. Of these 250 companies, nine were chosen as a sample. Among the nine, Occidental Petroleum reported a FAS123(R) expense of \$29 million and a tax deduction of \$353 million (a difference of $\$ 324$ million, or 1216\%), United Health showed an expense of \$46 million versus a deduction of \$318 million, and Cisco systems expensed $\$ 21$ million and took a deduction of $\$ 170$ million. Collectively, the sample expensed $\$ 0.2$ billion under FAS 123(R) and deducted $\$ 1.56$ billion for taxes, a $\$ 1.36$ billion difference with an average of $\$ 140$ million that reflects the average of the entire data set. 
While Senator Levin is alarmed by the huge gap between the ESO tax deduction and the ESO expense reported to stockholders, his main concern is not the $\$ 15$ billion the Treasure lost due to the deduction. After all, the executives paid tax of approximately equal magnitude on the same amount of gains they reported. Instead his main concerns have much to do with financial accounting theory and practice issues that both the FASB and those who practice accounting should also be concerned about. First, Senator Levin notes that the ESO expenses are the only compensation expenses that are reported many years after the costs are incurred by the companies. Second, he states that the ESO expenses reported to stockholders are not the true economic injury to the corporation, exercise date intrinsic values are.

\section{Senator Levin Proposes A Solution - The Gathering Storm}

According to Senator Levin the current state of ESO affairs do not make sense. Tax laws allow companies to take deductions that are 400 to 1200 times the expenses they report to the stockholders. Also, ESO are the only form of compensation and expense whereby companies are allowed to deduct more on their tax returns in the aggregate than they are allowed to expense in their books. If the expense amounts reported under FAS 123(R) over time and in the aggregate faithfully represent the fair values of the ESO, the tax rules must change to allow the tax deduction to occur when the options are granted and match the accounting expense amounts. In this manner companies could take the deduction years earlier which would treat ESO as every other form of compensation. However, there is a simple accounting alternative that will address Senator Levin's concerns without amending well established tax principles.

\section{A SIMPLE ALTERNATIVE ACCOUNTING MODEL FOR ESO: AN ILLUSTRATION}

If the intent of the FASB is to force firms to disclose the true economic cost to shareholders of issuing the ESO, then a model is needed that will allow accounting for changing economic conditions and flexible timing of exercise by option holders. The total ESO expense under the Simple model (S) is defined as follows:

$\mathrm{S}=($ period-end stock price - ESO exercise price $) \mathrm{x}$ the total ESO outstanding.

This calculation captures the intrinsic value of the total outstanding ESO obligation at the end of each financial reporting period (Illustration 1 - Panels A versus B). Financial statements would then record as expense (with a corresponding credit to paid-in capital from ESO):

Current ESO expense $=(\mathrm{S}-$ sum of previous expenses accrued $)$.

Under the Simple method, the current calculated amount of the ESO expense represents the incremental, or marginal, increase in the opportunity cost the firm has incurred since the last reporting period. This is the true economic cost to the firm for the reporting period and represents a dynamic estimate of the cost to shareholders resulting from the negative opportunity cash flows associated with the ESO exercise. In addition, there would be no expense in a quarter when there is a decline in the market price of the stock from the previous quarter. Under such a scenario there would be a recovery of a portion of previously recognized expenses, an amount which is again a faithful representation of the economic reality and cash flow consequences of the ESO.

The Simple model has several advantages over the BS and lattice models. First, it is easy to understand. Second, it does not require high implementation costs. Most importantly, it results in an expense amount that represents market conditions at the time when financial results are reported. In addition, it does away the need to justify dubious theoretical positions taken by the FASB when addressing the accounting for excess tax refunds and the classification of resulting cash flows in financial statements. Finally, it addresses the main complaint of Senator Levin by reporting to stockholders the true cost of compensation which can then be deducted on the tax return in the same year. The latter advantage will clear away the gathering storm and should compensate for the biggest obstacle against the adoption of any option valuation model which is the resulting negative impact on reported earnings. 
Meanwhile, the FASB has announced several projects that may eliminate theoretical obstacles to implementing the Simple model. The scope of the definitions of expenses and equities provided in the Statement of Financial Accounting Concepts No. 6 (SFAC 6) may be due for revision. Under current definitions, promises to issue stock at less than market value may not result in expenses, even though such promises result in negative cash flow consequences for the firm since the stock could have been sold at a higher price. The FASB has issued a pair of October 27, 2000 exposure drafts (file reference numbers 213B and 213C) concerning accounting for financial instruments with characteristics of liabilities, equities, or both, where the FASB noted its intention to amend the definition of liabilities and expenses to include obligations that can or must be settled by issuing stock. In addition, the FASB issued standard no. 150 as the first phase of implementing its views concerning accounting for financial instruments that have both equity and liability characteristics (FASB, 2003). As the FASB continues to implement this project and harmonize with IASB, the accounting method proposed in this article may be used to measure and report total cash flow impact of options on sponsoring firms.

\section{Illustration 1: An Example - Comparing FAS 123(R) and the Simple Model}

Data: A calendar year company grants ESO on January 1, 2005. Each option vests in two years and carries an exercise price of $\$ 10$ (par value $\$ 1$ ), the stock price on January 1, 2005. While quarterly measurements and reporting is required, only annual entries are shown to minimize detail. The stock price at December 31, years 2005, 2006, and 2007 are \$20, $\$ 30$, and $\$ 40$, respectively. The firm's effective tax rate is 40 percent during all years. FAS 123(R) fair value of the ESO on January 1, 2005 is estimated to be \$10. The option is exercised on December 31, 2007.

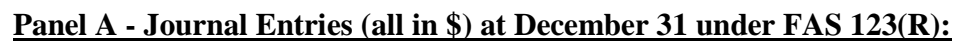

Cash

Additional PIC-Common

Deferred Tax Asset

ESO Expense

Tax Payable

Common Stock

Additional PIC-ESO

Deferred Tax Benefit (**)

\begin{tabular}{ccc}
\multicolumn{2}{c}{2005} & \\
\hline Debit & Credit \\
& & \\
5 & & \\
& \\
& \\
& 5 \\
& 2
\end{tabular}

2006

Debit Credit

2

5
$12(*)$

10

2007

$\frac{\text { Debit }}{10}$ Credit

27

4

$\begin{array}{lll} & 12(*) & \\ 5 & 10 & 1 \\ 2 & & \end{array}$

$\underline{\text { Panel B - Journal Entries (all in \$) at December } 31 \text { under the Simple Model: }}$

\begin{tabular}{|c|c|c|c|c|c|c|}
\hline \multirow[b]{3}{*}{ Cash } & \multicolumn{2}{|c|}{2005} & \multicolumn{2}{|c|}{2006} & \multicolumn{2}{|c|}{2007} \\
\hline & Debit & Credit & Debit & Credit & Debit & Credit \\
\hline & & & & & 10 & \\
\hline Additional PIC-Common & & & & & & 39 \\
\hline Deferred Tax Asset & 4 & & 4 & & 4 & 12 \\
\hline ESO Expense & 10 & & 10 & & 10 & \\
\hline Tax Payable & & & & & 12 & \\
\hline Common Stock & & & & & & 1 \\
\hline Additional PIC-ESO & & 10 & & 10 & 30 & 10 \\
\hline Deferred Tax Benefit (**) & & 4 & & 4 & & 4 \\
\hline
\end{tabular}

(*) Reduction in the Tax Payable in excess of the Deferred Tax Asset eliminated (\$8) is treated as a financing cash inflow in the cash flow statement, leaving the operating tax outflows equal to the amount that would have been paid if ESO deduction was not taken. This issue is not applicable to Panel B.

$(* *)$ Essentially, this is a credit to Tax Expense. 


\section{SUMMARY AND CONCLUSIONS}

Escalating compensation packages to senior managers and investor disillusionment have resulted in growing calls for the expensing of ESO. While slow to respond, the FASB mandated the expensing of the ESO. The two primary methods used to value the ESO, the Black-Scholes closed form equation and the lattice model, suffer from several deficiencies. These include different treatments of the possibility of early exercise, the need to derive volatility estimates that play a critical role in the valuation of the actual option amount, the lack of liquidity associated with secondary markets, and extended vesting periods.

A Simple model for valuing the ESO is available that is easy to understand, would have a low cost of implementation, and offers a superior estimate of the true cash flow effects associated with the opportunity cost to shareholders of the ESO exercise. By re-estimating the fair values of ESO in succeeding financial statements, and allowing for the staggered exercise dates of option holders, the Simple model reflects the preference by investors as well as by Congress to have the sponsoring firms disclose the shareholder wealth effect associated with the opportunity cost of the option exercise over time and up to the date of exercise. Finally, the Simple model aligns the aggregate tax deductions with the total expense reported over time and averts the gathering storm.

\section{RECOMMENDATIONS FOR FUTURE RESEARCH}

Future research may focus on the impact of expensing the ESO on stock values. A sample of S\&P 100 firms may be first compared to all large, diversified companies. Next, the same samples may be contrasted to a sample containing firms of all sizes that offer ESO. Other studies may compare the impact of the financial results of the two ESO valuation methods sanctioned by the FASB to the impact that results when employing the Simple model. Finally, studies may focus on samples of companies with certain financial characteristics or those operating in certain industry sectors.

\section{REFERENCES}

1. Aboody, D., Barth, M. E., and Kasznik, R., (April 2004), SFAS 123 Stock-Based Compensation Expense and Equity Market Values, The Accounting Review, 251-275.

2. Aboody, D., Barth, M. E., and Kasznik, R., (May 2004), Firms' Voluntary recognition of Stock-Based Compensation Expense, Journal of Accounting Research, 123-150.

3. Accounting Principles Board, (October 1972), APBO No. 25: Accounting for Stock Issued to Employees. American Institute of Certified Public Accountants (AICPA), New York.

4. Apostolou, N., and Crumbley, D., (May 2001), Accounting for Stock Options: The Controversy Continues, The CPA Journal, 34-39.

5. Apostolou, N., and Crumbley, D., (August 2005), Accounting for Stock Options: Update on the Continuing Conflict, The CPA Journal, 30-33.

6. Balsam, S., (December 1994), Extending the Method of Accounting for Stock Appreciation Rights to Employee Stock Options, Accounting Horizons, 52-60.

7. Barenbaum L., Schubert, W., and O'Rourke, B., (December 2004), Valuing Employee Stock Options Using a Lattice Model, The CPA Journal, 16-20.

8. Baril, C. P., Betancourt, L., and Briggs, J. W., (December 2005), How to "Excel" at Options Valuation, Journal of Accountancy, 57-63.

9. Bartow, E., and Mohanram, P., (October 2004), Private Information, Earnings Manipulations, and Executive Stock-Option Exercises, The Accounting Review, 889-921.

10. Baviera, G. J, and Walther, L. M., (May 2004), Stock Option Accounting: Defying the Usual Answers, The CPA Journal, 36-38.

11. Beams, J. D., Amoruso, A. J., and Richardson, F. M., (December 2005), Discretionary Reporting of Stock Options by IPO Firms, Accounting Horizons, 223-236.

12. Best, R., Rue, J., and Volkan, A., (Winter 2002), Impact of Stock Options on Quarterly EPS: A Proposal for Change, International Business and Economics Research Journal, 73-82. 
13. Black, F., and Scholes, M., (May 1973), The Valuation of Option Contracts and a Test of Market Efficiency, The Journal of Finance, 399-417.

14. Botosan, C., and Plumlee, M., (December 2001), Stock Option Expense: The Sword of Damocles Revealed, Accounting Horizons, 311-327.

15. Briloff, A., (December 2003), Accounting for Stock Options, The CPA Journal, 12-15.

16. Carter, M. E., Lynch, L. J., and Tuna, I., ((March 2007), The Role of Accounting in the Design of CEO Equity Compensation, The Accounting Review, Vol. 82 (2), 327-357.

17. Dechow, P., Hutton, A., and Sloan, R., (Supplement 1996), Economic Consequences of Accounting for Stock-Based Compensation, Journal of Accounting Research, 1-20.

18. Delves, D., (December 2002), Trend or Foe? Analyzing What's Behind and Beyond the Current Stock Option Expensing Movement, Strategic Finance, 36-41.

19. Deshmukh, S., Howe, K. M., and Luft, C., (July 2004), Stock Option Expensing and Corporate Governance: When Will the Debate End?, Strategic Finance, 41-44.

20. Doyle, W., (February 1997), New Accounting Principles for Stock-Based Compensation, Management Accounting, 38-42.

21. Dyson, R. A., (August 2004), Accounting for Stock-Based Compensation: A Simple Proposal, The CPA Journal, 6-10.

22. Eaton, T. V., and Prucyk, B. R., (April 2005), No Longer an Option, Journal of Accountancy, 63-68.

23. Financial Accounting Standards Board, (December 1978), FASB Interpretation No. 28: Accounting for Stock Appreciation Rights and Other Variable Stock Option or Award Plans, FASB, Norwalk, CT.

24. Financial Accounting Standards Board, (1985), Statement of Financial Accounting Concepts No.6: Elements of Financial Statements, FASB, Norwalk, CT.

25. Financial Accounting Standards Board, (July 1986), Discussion Memorandum: Accounting for Stock Options, FASB, Norwalk, CT.

26. Financial Accounting Standards Board, (1993), Exposure Draft: Accounting for Stock-Based Compensation, FASB, Norwalk, CT.

27. Financial Accounting Standards Board, (1995), Statement of Financial Accounting Standards No 123: Accounting for Stock-Based Compensation, FASB, Norwalk, CT.

28. Financial Accounting Standards Board, (October 2000a), Exposure Draft: Proposed Amendment to FASB Concept Statement \#6 to Revise the Definition of Liabilities, FASB, Norwalk, CT.

29. Financial Accounting Standards Board, (October 2000b), Exposure Draft: Accounting for Financial Instruments with Characteristics of Liabilities, Equities, or Both, FASB, Norwalk, CT.

30. Financial Accounting Standards Board, (November 2002a), Invitation to Comment: Accounting for StockBased Compensation, FASB, Norwalk, CT.

31. Financial Accounting Standards Board, (December 2002b), Statement of Financial Accounting Standards No. 148: Accounting for Stock-Based Compensation-Transition and Disclosure, FASB, Norwalk, CT.

32. Financial Accounting Standards Board, (May 2003), Statement of Financial Accounting Standards No. 150: Accounting for Certain Financial Instruments with Characteristics of both Liabilities and Equity, FASB, Norwalk, CT.

33. Financial Accounting Standards Board, (December 2004), Statement of Financial Accounting Standards No. 123 (R): Share-Based Payment, FASB, Norwalk, CT.

34. Financial Accounting Standards Committee of the American Accounting Association, (June 1994), Response to: FASB Exposure Draft - Accounting for Stock-Based Compensation, Accounting Horizons, 114-116.

35. Financial Accounting Standards Committee of the American Accounting Association, (March 2004), Evaluation of the IASB's Proposed Accounting and Disclosure Requirements for Share-Based Payment, Accounting Horizons, 65-76.

36. Financial Accounting Standards Committee of the American Accounting Association, (June 2005), Response to the FASB's Exposure Draft on Share-Based Payment: An Amendment of FASB Statements No. 123 and No. 95, Accounting Horizons, 101-114.

37. Finch, J. H., Rue, J. C., and Volkan, A. G., (March 2007), No More Scandals: A Simple Model for Valuing Employee Stock Options, Journal of Business and Economic Research, Vol. 5 (3), 37-44. 
38. Folami, L. B., Arora, T, and Alli, K. L., (September 2006), Using Lattice Models to Value Employee Stock Options Under SFAS 123(R), The CPA Journal, 38-43.

39. Frederickson, J. R., Hodge, F. D., and Pratt, J. H., (October 2006), The Evolution of Stock Option Accounting: Disclosure, Voluntary Recognition, Mandated Recognition, and Management Disavowals, The Accounting Review, Vol. 81 (5), 1073-1093.

40. Hemmer, T., Matsunaga, S., and Shevlin, T., (December 1994), Estimating the "Fair Value" of Employee Stock Options with Expected Early Exercise, Accounting Horizons, 23-42.

41. Hill, N., and Stevens, K., (1997), Instructional Case: Choices and Dilemmas in Accounting For StockBased Compensation, Journal of Accounting Education, Vol. 15 (7), 389-410.

42. Hull, J., and White, A., (2004, 1:1), Accounting for Employee Stock Options: A Practical Approach to Handling the Valuation Issues, Journal of Derivatives Accounting, 3-9.

43. International Accounting Standards Board (November 2002), Exposure Draft 2: Share-Based Payment, IASB, London.

44. International Accounting Standards Board (April 2004), IFRS \#2: Share-Based Payment, IASB, London.

45. Jordan, C. E., Vann, C. A., and Clark, S. J., (December 2005), The Financial Statement Effects of Expensing Stock Options at Fair Value: S\&P 500 versus Non-S\&P 500 Companies, Oil, Gas \& Energy Quarterly, Vol. 54 (2), 273-281.

46. Kirschenheiter, M., Mathur, R., and Thomas, J. K., (June 2004), Accounting for Employee Stock Options, Accounting Horizons, 135-156.

47. Levin, Carl, (June 6, 2007), Executive Stock Options: Should the IRS and Stockholders Be Given Different Information?, Statement and Exhibit List at Senate Permanent Subcommittee on Investigations Hearing, pp. 1-14 and Exhibits 1-12.

48. Lobo, G., and Rue, J., (Summer 2000), Accounting for Stock Options: Comparison of Alternative Approaches, The Journal of Applied Business Research, 27-38.

49. Mellman, M., and Lillien, S., (March 1996), Stock-Based Compensation Effect on Net Income, The CPA Journal, 50-53.

50. Moehrle, S. R., and Reynolds-Moehrle, J. A., (June 2004), Transitioning to the Fair Value Method, The CPA Journal, 20-22.

51. Moyer, S., and Weihrich, S., (August 2000), Espresso, Inc.: Analyzing the Impact of Employee Stock Options, Issues in Accounting Education, 513-534.

52. O'Shaughnessy, J, and Rashty, J., (June 2007), Critical Accounting Estimates for Share-Based Payment Arrangements, The CPA Journal, 34-39.

53. Pacter, P., (March 1994), FASB's Stock Option Accounting Proposal: Correcting a Serious Flaw, The CPA Journal, 60-61.

54. Perspectives, (January-February 1994), Letters to the Editor, Harvard Business Review, 27-36.

55. Robinson, D., and Burton, D., (June 2004), Discretion in Financial Reporting: Voluntary Adoption of Employee Stock Options, Accounting Horizons, 97-108.

56. Rue, J., Volkan, A., Best, R., and Lobo, G., (November 2003), Stock Options Revisited, The CPA Journal, 34-40.

57. Siegel, M. A., (March 2006), Accounting Shenanigans on the Cash Flow Statement, The CPA Journal. 3843.

58. Tucker, J., and Shimko, B., (January 1995), The Economic Impact of the Proposed Rule Change for Employee Stock Options: The Issues and Controversy, American Business Review, 8-10.

59. Wallace, W., (April 1984), The Effects of Delays by Accounting Policy-Setters in Reconciling the Accounting Treatment of Stock Options and Stock Appreciation Rights, The Accounting Review, 325-341. 
NOTES 